\title{
Rendering the Fold
}

\begin{abstract}
Ailsa Kay
Rendering the Fold, d'Ailsa Kay, se présente comme une rêverie baroque portant sur la photographie et la psychanalyse, celles-ci tentant de "dévoiler le voile lui-même " et de pénetrer le "pli insaisissable ». Le pli, "unité fondamentale de tout vêtement drapé ", ressemble aux mystères de la fémininité, avec ses voilages, ses drapements et ses froissements. La viabilité de l'objet fétiche discret - "l'épingle à cravate d'ambre ", " une cravate bleu lavande " ou encore "la valise compacte" - est toutefois mise en doute par les bordures imperceptibles du pli entre l'intérieur et l'extérieur, et reflète une incapacité à séparer l'objet fétiche de son sujet.
\end{abstract}

There is a photograph of him. Of course there is. A photograph of the photographer and he is small with round cheeks, eyes no one would comment on. That photograph was taken by Estelle - a lovely woman who is not his lover. His lover, had he one, would not dress in such a way - would not wear the stiff collars, stiff waists, pressed cuffs of this age of thrift. His lover, had he one, would refuse the fashion of slight and tight. She would, instead, cut dresses for herself in huge swathes of silk. She would cut through silk the way he'd seen men scythe through hay, with wide gestures of her arm, taking in a chunk of world with each arc. The finished dress would engulf her, would wrap around her in layers so that the body, beneath, would be hard to find.

Estelle took his picture because he needed one quickly for the Ecole. They had asked him to teach a course this fall and requested a picture that they might display, along with those of other professors, in little ovals in one large frame that hung in the pale green hallway outside the office of the principal. Estelle had ducked under the cloth that he so often ducked under himself, had arranged him in front of a dark background - the curtains of his study - and had told him not to blink. Holding his hat in his hand, perched on a stiff-backed chair, Clerambault wanted nothing more than to blink. He wanted to blink so badly, his eyes hurt. They watered. In the photograph, his eyes shine with what seems like fervour. Or happi- 
ness, perhaps, though he does not smile. Estelle doesn't tell him he looks handsome, or that his suit is well-cut. She takes the picture as though she's sick of looking at him already - impatient. She snaps the shutter like she washes dishes: noisily and fast.

She was the one who found him. He'd stationed himself in an armchair in front of the mirror, as though to catch himself in the act of dying. The note he left was all about the loss of his eyesight. And should his eyes survive the blast, he would like to donate them to science. Estelle found him and didn't scream, just a quick intake of breath and a feeling in the throat like she'd swallowed a spoon. The armchair held his body like a sack of laundry. At the back of the chair, and supporting it, arresting its fall at the moment of the blast, was his bed. Before loading the gun he'd arranged all of the furniture precisely: mirror, armchair, bed as a buttress, dragging the heavy armchair from the window into position, trying it out, then realizing that he did not want to die staring at a wall filled with the work of his life. It would be read as symbolic: the photographer confronted by his photography. Bullshit. Bullshit journalists would find symbols in their grandmother's chamber pots. Fine, he'd give them a symbol. And so next the mirror. A standing mirror, heavier than the armchair, preposterously large for such a small man. His reflection occupied about half of it, and that from a close distance. But this, too, was a collector's item. He'd brought the frame back from Morocco; once upon a time it had belonged to some colonialist there who'd fallen on hard times. He'd found it at a flea market. The frame was ebony and carved with elephants. He seated himself before it, thought: Man dies looking at himself. Made sure the armchair was well braced by the bed. Put his eyeglasses on the floor by his feet.

Estelle was in the kitchen when she heard the blast. It was the second shot she'd heard this morning. Earlier, he'd been in the garden, trying out his old army pistol, firing it into the air for apparently no reason. When he came back in, he'd marched straight through the kitchen where she was at the table enjoying a cup of coffee, and he hadn't said a word. She was unperturbed by this behaviour, as she told the police later, because he had a familiar air about him. She'd seen him like this before; bristling, brisk. It usually preceded a bout of work. True, he didn't normally begin work by firing a shot into the air but - and she recognizes that this sounds absurd given the outcome - but she interpreted the shot as a display of excitement at the beginning of a new project. On your mark, Go. A starter's pistol. He had not worked in months. 
In the armchair, dead, he looked like the beanbag doll she'd had as a child. Estelle turned. She would make sense of it later. Now she went briskly downstairs to phone the police, taking the steps quickly, evenly, back straight. On the last step she caught the heel of her shoe on the carpet and, grabbing onto the hat stand to break her fall, sent bowlers and derbies flying. Shit! Too full, this house! Have to move that stand. She thought, amazed, in the moment of thinking, hats in the air, that such an ordinary thought would shoot so quickly to the surface. She shouldn't be surprised. Her dying grandmother, in the last throes of a long illness, had still managed to bark out "Wipe your shoes!" The banal and the extraordinary don't rule each other out.

Right away Estelle called the police and the doctor. Though what either of these parties was going to do, she wasn't sure. The police to say yes he killed himself, the doctor to say yes he's dead. The official statement of the obvious. He, no doubt, would like the police to note that he'd taken his glasses off and placed them on the floor beside him, that he'd lined up the shotgun so that he would miss his eyes, that the gun was his army pistol, that the mirror was heavy to drag across the floor and that he must have thought carefully about the arrangement of the room before pulling the trigger. He would, without a doubt, want those who attended the scene of his suicide to be observant of every detail. As observant as he himself would have been.

The two policemen and one doctor stood around the body of the little man, whose feet in pointy shoes did not quite reach the floor. The pistol had fallen from his hand. One policeman had the note. He read it, passed it to the doctor who put his glasses on to read. He opened his mouth slightly, tipped his head to look straight down his nose. "Hunh," he said when he finished reading. And he bent down to look Gaetan Gatian de Clerambault in the eyes: "What are you looking at, you puny bastard?" $\mathrm{He}$ said it affectionately, for he had been the one to give Clerambault the prognosis not five years ago: Colours giving way to shadows and light giving away, eventually, to the loss of both. Blindness.

Between the photograph and the pistol, fifteen years. Estelle who was lovely when she took the picture was still lovely when she attended the funeral, though somewhat thicker about the waist. She'd recently plucked five grey hairs from her head. The whole of the French psychiatric establishment was there. Charcot, etc. Jacques Lacan, who wore a turban for the occasion. A joke at the expense of the dead. There are pictures of the bunch 
of them, Lacan front and centre in most. In one, they've wrapped a tablecloth around him and he strikes a pose that resembles the statue of liberty. The fabric falls from his left shoulder and is hooked under his right arm, held in place by Charcot's index finger. The folds are loose, the tablecloth being of a soft fabric. The expression on his face is false sobriety. Charcot's face is turned away from the camera. His face is old and in the way he sticks his finger into Lacan's side, one might be tempted to read Oedipus. The father desiring the death of the upstart son. Then again, it could as easily be Doubting Thomas - Stick yer finger in there son! says Lacan to Charcot.

At the time of the photograph, though, the one Estelle took, he's not dead yet. Far from it. He's alive and he's got a hard-on. "Very good, Estelle, thank you," he says, hopping off his chair and putting his hat on his head. "I will eat at five tonight, remember, as I am teaching in the evening." Of course she remembered, he said it for himself. Teaching. Teaching at the Beaux Arts.

Tonight he would wear his coffee coloured light wool suit, and a darker brown plaid waistcoat. Dignified but artistic. A lavender cravat, he thought. A tie-pin of amber. Already he'd chosen the swathes of fabric he would use in the first demonstration: the simplest, most eloquent fabric: white silk, dried in the desert air, still sandy, stiff. Smelling, still, of Morocco. When he'd taken it out of the cedar chest this morning, he'd plunged his face into it, deep breath of Arab. Sand, souq, cedar, dry dry air. Very faintly, the musk of semen. Or perhaps he was imagining that, but still the resulting erection was nothing to sneeze at, Good Lord! Standing there with only his shirt on, he clenched and unclenched the muscles of his buttocks, inwardly cheering for his handsome, bobbing member. Oh my, oh my, oh my - it's going to be a good day. Glancing at his watch, he hurried into his pants and called Estelle to take his photograph. The photograph of the photographer, explorer of the Fold. He holds his hat demurely over the bulge in his pants, swells his chest, looks straight into the lens.

Before the photograph, in Morocco, where it all started, Clerambault is in his army tent with two Arab girls - sisters. The light filters through, sepia toned, desert toned. There is sand between his toes, and everywhere in the folds of his clothes. The girls are draped in the stiff white silk that he loves, they cover their faces and giggle at him, at each other, as he undresses. His wound is still bandaged and lumpy. He stands on solid, 
muscled legs covered in black hair. His chest is also covered in hair, as is the paunch that he sucks in. He approaches the girls. Twirls them, first one, then the other, as though they are slow spinning tops - around and around. The fabric that clothes them fills with air, billows just slightly. $\mathrm{He}$ stands between the two twirling, laughing girls, winding them closer until they are, all three, only spinning, silk, and skin. Spilled seed.

There are, preserved for posterity in the Musée de l'Homme, 40000 photographs taken by the little Frenchman, de Clerambault. Their subjects vary only in terms of posture and number. Sometimes there is one, sometimes two, sometimes a whole crowd - women congregated at a well, behind a wall, women and men on their way to the mosque. Sometimes a solitary figure appears in numerous shots. In each shot, a different posture: right arm perpendicular to the body; both arms raised; torso bent as though to pick, from the stony ground, a piece of glass. For the photographer, the people who pose for him - who squat, bend, swing their arms, throw handfuls of sand into sky, fingers opening - these people are incidental. What he hopes to capture, each of the 40000 times he clicks the shutter, is nothing human. He does not document a tribe, a nature, a condition, an emotion. Though he is a psychiatrist by training, he has no interest, here, in human misery. Psychiatry has no place in the Orient. It has no substance in a place like this where the living walk about in shrouds. In Morocco he does not investigate the contortions of the mind, but the contortions of the body. No, not even the body but its extension - the body manifest.

The police prefecture, where he's been employed since before the war, adjoins the courthouse. Its floors are wood, varnish flaking off, its walls all yellowed white. Its windows are small and grilled, and it smells of disinfectant and pill bottles and, this morning, chrysanthemums. Someone has put a pot of them on the table in the hall as though to cheer things up. It is generally quiet, in the morning. Hospital quiet. Some patients still sleeping. Some sitting up, drinking their weak tea or coffee. There is water running somewhere, pipes clanging. And someone humming. As he bustles past the red chrysanthemum toward his office, he is going over, yet again, his opening remarks.

Art veils the physical world in beauty. Science, in its pursuit of knowledge, unveils it. Beauty and knowledge, gentlemen. Veiling and unveiling. (He would want to pause here, with a self-denigrating, wry smile, acknowledging the somewhat overblown nature of his words. The tone of the following 
would be sterner, clean-edged.) Today, we will do away with the distinction between these two pursuits.

Yes, how perfectly he had phrased that, how perfectly that summarized his task. And he could envision, now, the effect such language would have on his audience. Their eyes would open wider. The shuffling of papers, feet, little rustlings of movement would stop. He would strike a chord with that phrase. He would silence them, hold them in the palm of his hand.

But he is not there yet. He is in his office at the Prefecture and the curtains have been opened and the hysteric has been summoned and she sits in the chair on the other side of his desk, her hands quiet, now, and safe in her lap, one gently cupping the other. Clerambault's feet in their pointy shoes are crossed tidily under his desk as he opens his file, dips a pen in his well and focuses his gaze (that legendary gaze) on the woman before him: Rose.

Docteur: Let's begin. I do not need to explain, I assume, what you're doing here and who I am? Good. First, how did this happen?

$R$ (in his notes, patients are always referred to by an initial only): You mean what did I do? Or why did I do it? (pause). She was being such a brat you don't know. Pulling on the cloth as I tried to sew, crying, crawling under my chair and pushing the treadle - I was making a blouse for myself. I wouldn't say it was like an idea I had to do it. I wouldn't say that, exactly. It was more like a shout or a curse - you don't have an idea to shout, you just do. (She frowns, bites her lip as though she's about to cry.)

Docteur: And how did you feel, after you'd done it?

R: It was awful. Awful. What kind of mother treats her daughter like a pincushion? (A pause.) Have you spoken to my husband?

Docteur: I'm afraid I can't. Apparently he's turned into a thimble.

Clerambault cleared his throat, covering the laugh that had caught him off guard. Encore.

Docteur: I have not. We have an interview this afternoon. Is there anything you would like to say to him? 
R: No. I imagine there's a few things he'd like to say to me.

Docteur: You know he's the one who brought you here, who had you arrested.

R: Yes. I'm not senile. (Her tone is abrupt, not empassioned or angry.)

Docteur: This is not the first time this has happened. Last time it was your own flesh that you stuck full of pins. So why do you do it, do you think?

R: My memory, I repeat, is fine Doctor. I remember each occurrence perfectly. (She looks away, to her right, out the window.) As for why - why, why, why, why. (In the French - which is, lest we forget, the language which both patient and doctor are speaking, the language of this whole story - "why" is "pour quoi" or "for what?" So she says, in fact, "for what and for what and for what and for what.") Pour joie, et pour joie et pour joie. Non. Pas pour joie. Je ne sais pas. Parce que je suis folle. Parce que je suis folie, en guise de raison. N'est-ce pas?

Docteur: I do not think that likely, Madame. (Around his head, a fly buzzes, he swats at it distractedly.) I think you are ill. That you have an illness. We will diagnose that illness. We will prescribe a treatment and Again the fly, this time at his chin. He bats it away - you will get better. Describe for me, please, the first episode.

As R. talks, the fly bangs against the window. Bumps and buzzes, refusing to settle. Clerambault's peripheral vision is invaded again and again by the irritating bug. He shifts in his chair, puts his left hand to his face as though to shade his eyes. Better. The woman is educated. She speaks with the casual superiority of one who has spent too much time reading. She has the body of a swallow - douce et petite. Not unattractive but too round for his taste. Her dark hair is a mess, her clothes untucked and her face sags. After an hour, he has heard all he wants to and escorts her to the door.

He rolls a sheaf of paper. Stalking the fly, he thinks to himself: My taskour task - is to document and classify the various manifestations of this elusive, ever moving object so that it can, in turn ... -No, perhaps drop the "ever moving" - too wordy. "Elusive" is good though: precise. Precisely elusive. 
Elusively precise. Whack! Clerambault dances around his desk, jumping to smack the ceiling, the motionless ceiling fan, the dusty upper shelves of his book case. The fly out-maneuvering him each time. Whack! Whack!

"Doctor de Clerambault?" The voice, a female one, is from the hallway. He pauses in his activity, turns. The sun streams through the window, lighting his desk and cutting him in half, obliquely. Dust, disturbed by his activity, swirls in dancing particles around his legs. "Hello?" he says, momentarily unable to see, for the angle of light, the figure who hesitates in the dim hallway just outside his door.

"Perhaps you don't remember me: VB."

Stop.

VB too was at his funeral. She stood, in her navy suit, apart from the psychiatrists. By this time, her dark hair was greying and the skin of her hands beginning to crepe. Her neck, too. She watched her own aging, amazed and horrified. Her skin was everywhere loosening. It was like walking around in somebody else's old underwear, the elastic shot. She hated it, this becoming old. And the funerals. The drab, sad faces. As they lowered Clerambault into the ground, as the priest intoned, her mind wandered. To thoughts of her own aging, her own tombstone, who would take care of her in her senility. She was not rich enough to afford a nurse and she had no children so the most she could hope for was one of those neighbourly types (one of those fat cluck-clucking types) to stop by occasionally with little pots of soup and neighbourly prattle. Normally, she brushed by such women on the street walking as quickly as she could, her heels knocking decisively on the pavement so as to prevent their friendly approaches. "Don't you look lovely today," she'd get, shouted from curbside or behind gates. Or, "In a hurry then are you? What's he look like?" She'd wave, smiling, and keep going. Or she'd reply, still in motion, "I have an appointment!" or "What a beautiful day!" She was unskilled when it came to trading pleasantries and, though she knew the deficiency was certainly her own, she'd always resented the imposition of other people's chatter. How some people felt the lines differently and had no difficulty hurdling hers. If she were old and ill would they even bother stopping in to see her or would she have so alienated them by that time that they would cross their fat arms and watch, from their front steps or over their window boxes, as she shriveled. As she made her way, bent double with age, to the corner for her little pastry and coffee. Still trying to click her heels decisively against the pavement. 
"Well that's that." She started at the voice beside her. People were turning their backs on the grave now, making their way across the grass that was, for November, insultingly green. The funeral was over, Clerambault tucked neatly into eternity. She pulled the scarf from her neck - it was silk, heavy white silk embroidered with a small red pattern - and held it over the grave. Her plan was to drop it onto the coffin, an appropriate and, she thought, picturesque gesture to end her last conversation with the doctor. But standing there with the sun shining and the grass green, and the wind blowing so that it snapped the scarf against her extended arm, she felt foolishly melodramatic. So she shook the scarf out as though that had been her intention all along, letting it billow a moment as she held it by two corners before tying it round her head like a kerchief. She then turned and walked quickly away, her sharp heels sinking into the sod, wobbling her otherwise upright posture.

Clerambault scrambles down from his desk, smoothes his tie, his jacket. "I'm sorry," he says, "you are, again?" The woman has stepped into his office now and stands before him. Her suit is fashionably modern, navy blue and plain. She is tall, small boned, olive skinned. She is not young, he thinks, but attractively well-preserved.

"In your article of 1908, I appear as VB," the woman replies. "My full name is Vera Barshovski."

It was perhaps coincidence that Vera Barshovski appeared in his office the day of his first lecture at the École de Beaux Arts. Definitely, it was coincidence; Clerambault was not a mystic. He had no belief in universal forces at work. He thought the unconscious was a crock. It was a co-incidence, the momentary and surprising intersection of two separate events significantly, albeit not obviously, connected. The connective tissue of his life, he would later think, the connective tissue that turns life from a random assortment of incidents into an object of aesthetic appreciation. That's what coincidence is. Does. This thought did not come to him until many years later, when his vision was already deteriorating, when he could no longer read for more than an hour at a stretch and was forced to lie, inactive, on his couch while his eyes rested. Most of his thoughts during this period were depressing reiterations of his condition and his future. His brain was a tired dog, chasing its tail. But occasionally past moments would come at him in full colour, full detail. And, remembering, he'd marvel at his coincidences in a way he'd been unable to do, living them. VB unbelievable! 
Immediately she pronounces her name, he sees her. He sees both the face he'd known seventeen years before and the face before him. Vera Barshovski: 1906 and 1923. It is incongruous.

"Mademoiselle Barshovski. I remember." A combination of embarassment (the fly), curiosity (what did she want?) and impatience (because he has other things on his mind today, not the least of which is his lecture). Also a low nudge of desire, perhaps just the after-shock of this morning's erection. There is an awkward pause as he waits for her to explain her presence. "I don't normally grant appointments with ex-patients," he prompts.

Vera does not reply immediately but studies, with a flat scrutiny, the man who stands, leaning against his desk with hands in his pockets, before her. "I am cured," she said. "It had nothing to do with you but I thought you might be interested to know how. In case there are others like me. In case you want to write a book." Her words, as they emerged from her lips were so decisive, self-assured. As though they'd been a long time coming, a long time waiting to be said. They were words like solid objects, like heavy books laid one on top of the other. Thunk. Thunk. Thunk. In fact, she had not set out that morning for the Police Prefecture to address the psychiatrist who'd had her committed so many years ago now. She had not set out with anything in mind at all, other than a walk. Fall air. Blue sky, leaves turning, all that. And here she is, pronouncing words like heavy books as though they bore the weight of authority. God knows what she'll say next. She tilts her chin, waiting for the doctor's response. Waiting for her own.

Clerambault is conscious of the fly still buzzing, banging into the glass. He is also conscious of the itchiness of his wool pants, the tightness of his collar, the dust in the air that is making him want to sneeze. Legions of irritants, more massing on the horizon. "Thank-you," he smiles tightly, "I am not interested in writing a book of cures." There is the barest pause as the two face each other, Vera composed and still somewhat curious as to where this interview might lead, Clerambault trying to ignore the itch in his nose.

Achoo!

From her handbag, Vera extracts a pale yellow handkerchief. It is silk. She has pressed it into a perfect rectangle so that when she shakes it out, holding it by one corner between her two fingers, the fabric holds its perfect creases. "Please," she says, shaking it toward him without moving any 
closer so that the gesture seems strangely like a dare. "Here," she shakes it again at the end of an extended arm. "You should dust, now and then." Clerambault concludes his introduction: And what is that object, Gentlemen? The object of our scientific and artistic inquiry? It is nothing less and here he pauses, surveying the hall - than the Fold. The Fold, I will argue, is the basic, fundamental unit of any draped garment and my hypothesis is that, like various forms of architecture, its history can be understood through classification. My task - our task - is to document and classify the various manifestations of this elusive, this transitive object. Gentlemen, we are about to unveil the veil itself.

And then, with a click, he opens his valise. 